\title{
Heat stability of micellar casein concentrates as affected by temperature and $\mathrm{pH}$
}

\author{
A. Sauer and C. I. Moraru ${ }^{1}$ \\ Department of Food Science, Cornell University, Ithaca, NY 14853
}

\section{ABSTRACT}

The increased interest in using micellar casein concentrates (MCC) obtained by microfiltration in the manufacture of shelf-stable high-protein beverages creates a need to understand the effect of sterilization treatments on the stability of this ingredient. The goals of this work were to (1) elucidate the effects of $\mathrm{pH}$ and heat treatment temperatures in the sterilization range on the stability of MCC, and (2) use the generated knowledge to develop solutions for stabilizing the MCC during sterilization treatments. Micellar casein concentrate powders were reconstituted, and the resulting casein dispersions were adjusted to $\mathrm{pH}$ values of 6.5 to 7.3. Subsequently, the MCC samples were heated in an oil bath to 110 to $150^{\circ} \mathrm{C}$. The treated samples were evaluated for particle size, soluble minerals, and casein dissociation. At $\mathrm{pH}$ $<6.7$, all heat-treated samples were visibly aggregated or coagulated. At $\mathrm{pH}$ 6.9, higher temperatures led to increased particle size, whereas at $\mathrm{pH}>6.9$, few or no changes were observed after heat treatment. Casein dissociation increased with increasing $\mathrm{pH}$ for all caseins, at all temperatures, with dissociation of $\kappa$-casein and $\beta$-casein being the most pronounced. At higher $\mathrm{pH}$, the levels of dissociated $\alpha_{\mathrm{s}}$-casein decreased after heat treatment, suggesting aggregation of $\alpha_{\mathrm{s}}$-casein in the presence of $\mathrm{Ca}$ and protection lost by $\kappa$-casein. It was concluded that increased stability of MCC requires increasing the $\mathrm{pH}$ or lowering the processing temperature. After applying these modifications, MCC was submitted to both retorting and UHT sterilization, at equivalent lethality. A significant reduction in particle size was obtained and no coagulation or aggregation occurred after retorting or UHT under the modified conditions as compared with the controls. The knowledge generated in this study will allow the effective stabilization of MCC in practical applications, such as the production of high-protein, shelf-stable beverages.

Key words: micellar casein concentrate, sterilization, casein dissociation, microfiltration

Received May 9, 2012.

Accepted July 11, 2012.

${ }^{1}$ Corresponding author: cim24@cornell.edu

\section{INTRODUCTION}

The use of micellar $\mathrm{CN}$ preparations obtained by microfiltration is receiving increasing interest from the dairy industry and other industries (Affertsholt, 2009). In the microfiltration ( $\mathrm{MF}$ ) process, $\mathrm{CN}$ is separated from serum proteins based on their difference in molecular size (Brans et al., 2004), with additional diafiltration of the retentate leading to serum protein removal of up to $95 \%$ (Nelson and Barbano, 2005). In CN concentrates obtained by $\mathrm{MF}$, the $\mathrm{CN}$ micelles are closer to their native state than in CN preparations obtained by chemical methods. This results in unique functionality and opens the field for possible applications of the CN concentrates, such as premium shelf-stable, highprotein nutritional beverages (UBIC Consulting, 2010). Typically, the manufacture of such beverages involves a sterilization step; therefore, it is crucial that the $\mathrm{CN}$ concentrates are heat stable under a range of $\mathrm{pH}$ and temperature conditions.

Casein micelles in milk are remarkably stable systems that can withstand the rigorous conditions applied during commercial processing (Fox, 1982). However under certain conditions of temperature and $\mathrm{pH}$, the colloidal integrity of the $\mathrm{CN}$ micelles can be disrupted, resulting in decreased stability, as manifested through visible flocculation, gelation, or protein separation (Fox, 1982).

The mechanism and the $\mathrm{pH}$ dependence of heatinduced instabilities of the CN micelles have been the subject of previous research, most of which has been done on milk and concentrated milk products; only some studies are available on micellar CN systems devoid of serum proteins and lactose.

Previous work has investigated the effects of 2 commercial sterilization regimens (continuous-flow UHT treatment and in-container retorting) and spray-drying on the stability and physical properties of micellar CN concentrates (MCC) during processing and storage (Sauer and Moraru, 2011; Beliciu et al., 2012). Sterilization affected the colloidal stability, viscosity, and flow behavior of MCC. Retorting resulted in a significant increase in particle size, whereas UHT treatment caused aggregation and coagulation of the MCC. The observed effects were credited in part to a loss in solubility of 
Ca phosphate as a result of the high heat treatment, but it was hypothesized that $\mathrm{CN}$ micelle dissociation also likely played a role in this instability (Beliciu et al., 2012).

The objectives of this work were to 1) elucidate the effects of $\mathrm{pH}$ and heat treatment temperature on the mineral distribution and dissociation of $\mathrm{CN}$ micelles, and 2) use the generated knowledge to develop solutions for stabilizing MCC during sterilization treatments.

\section{MATERIALS AND METHODS}

\section{MCC}

The MCC was obtained by membrane separation in the pilot plant at Cornell University following the methodology described in detail by Hurt et al. (2010). Pasteurized skim milk was subjected to 3 stages of MF using a uniform transmembrane pressure system equipped with ceramic Membralox membranes (Pall Corporation, Port Washington, NY) of $0.1-\mu \mathrm{m}$ pore size. After the first and second MF stages, the resulting retentates were diluted with reverse osmosis water at a 2:1 ratio (by wt; 2 parts water, 1 part retentate). The final retentate was spray-dried using a Model 1 Niro Atomizer equipped with a FU11 atomizer rotating at 23,000 rpm (Niro Atomizer Inc., Columbia, MD). The inlet air temperature was $200^{\circ} \mathrm{C}$, and the outlet air temperature was $95^{\circ} \mathrm{C}$. The spray-dried powder was stored in tightly closed containers in the dark at room temperature $\left(25^{\circ} \mathrm{C}\right.$ or less $)$ until use.

\section{Experimental Design}

The MCC powder was reconstituted in water and adjusted with $1 \mathrm{M} \mathrm{HCl}$ and $1 \mathrm{M} \mathrm{NaOH}$, respectively, to $\mathrm{pH}$ values ranging from 6.5 to 7.3 . To study the effects of $\mathrm{pH}$ and temperature in the sterilization range, samples were heat treated using a benchtop heating system. To minimize the number of experiments, $\mathrm{pH}$ and temperature conditions were chosen based on an experimental design derived from the central composite design of response surface methodology. Specifically, central and corner points of the range of conditions to be investigated were chosen, to span a larger range of the effect variables, as shown in Figure 1. Non-heattreated samples (controls) were analyzed at all $\mathrm{pH}$ conditions.

After investigation of the full range of $\mathrm{pH}$ and temperature conditions, commercial sterilization regimens for the UHT and retort treatments were designed based on optimal $\mathrm{pH}$ and temperature combinations as well as legal sterilization requirements for the dairy industry.
All treatments and analyses were performed in triplicate.

\section{Chemical Analysis}

Fresh liquid MF retentates were analyzed for lactose, fat, and true protein by Fourier transform infrared spectroscopy (FTIR) by using an infrared spectrophotometer (LactoScope FTIR, Delta Instruments, Drachten, the Netherlands) before spray drying. The powder was reconstituted to $10 \%$ solids and was analyzed at Dairy One Inc. (Ithaca, NY) for fat by ether extraction (AOAC International, 2000; methods 989.05 and 33.2.26), and for proteins by Kjeldahl:total nitrogen (AOAC International, 2000; methods 991.20 and 33.2.11), NPN (AOAC International, 2000; methods 991.21 and 33.2.12), and non-CN N (AOAC International, 2000; methods 998.05 and 33.2.64). The TS content of the powder was measured by forced-air ovendrying (AOAC International, 2000; methods 990.20 and 33.2.44). The chemical composition of the $95 \%$ serum protein-reduced MCC powder is presented in Table 1.

\section{Sample Preparation}

The MCC powder was reconstituted to CN concentrations of $8 \%(\mathrm{wt} / \mathrm{vol})$ in water. This concentration was chosen based on prior work (Beliciu et al., 2012) and on the typical protein concentration for a high-pro-

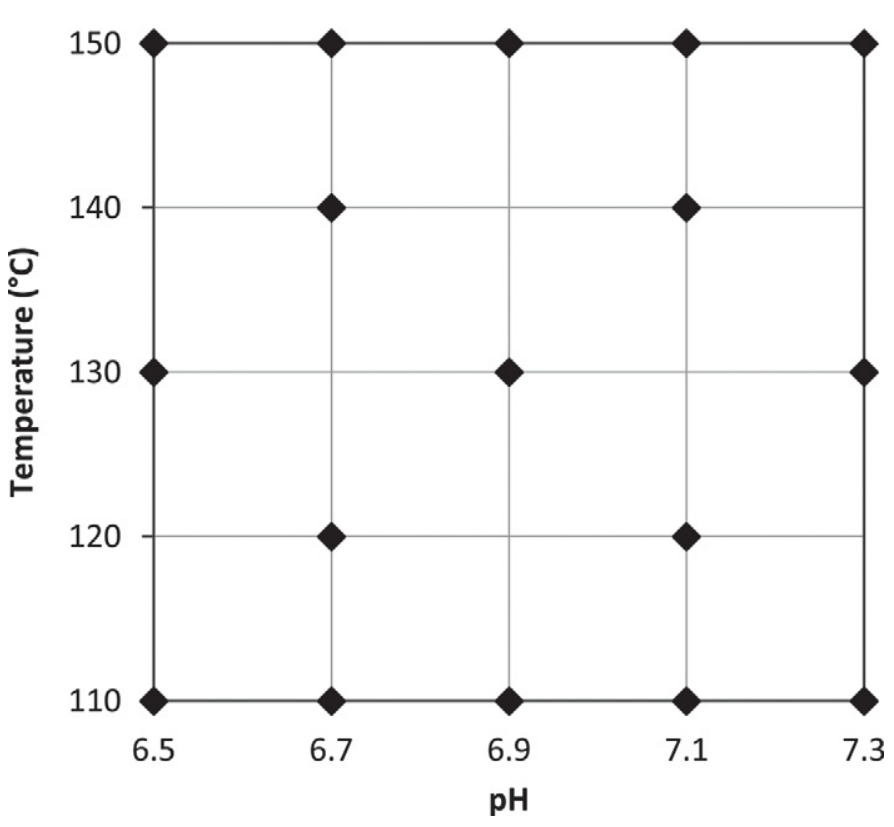

Figure 1. Experimental design: $\mathrm{pH}$ and temperature conditions chosen for the benchtop heat treatments. Non-heat-treated samples were analyzed as control samples at all $\mathrm{pH}$ conditions. 
Table 1. Chemical composition (\%) of the $95 \%$ serum protein (SP)-reduced micellar CN concentrates (MCC)

\begin{tabular}{lcccccc}
\hline & \multicolumn{7}{c}{ Chemical composition ${ }^{1}$} \\
\cline { 2 - 7 } Item & $\mathrm{TS}$ & $\mathrm{TN}$ & $\mathrm{NPN}$ & $\mathrm{NCN}$ & $\mathrm{CN}$ & Fat \\
\hline $95 \%$ SP-reduced MCC & 9.55 & 8.29 & 0.11 & 0.88 & 7.41 & 0.24 \\
\hline${ }^{1} \mathrm{TN}=$ total nitrogen, NCN = non-CN nitrogen. $\mathrm{CN}=\mathrm{TN}-\mathrm{NCN}$. & & &
\end{tabular}

tein beverage. The CN concentration of the MCC was estimated as $98 \%$ of the true protein values obtained by FTIR measurements (Lactoscope FTIR, Delta Instruments), according to the method of Hurt and Barbano (2010). True protein of the final MF retentate before spray-drying was $8.21 \%$, which equates to $8.05 \% \mathrm{CN}$.

For the benchtop treatments, ultrapure water was mixed with predetermined amounts of $1 \mathrm{M} \mathrm{HCl}$ and $1 \mathrm{M} \mathrm{NaOH}$, respectively, so that the MCC dispersions would reach $\mathrm{pH}$ values of $6.5,6.7,6.9$, and 7.3 . The control samples for the $\mathrm{pH}$ study were not adjusted and had a $\mathrm{pH}$ value of 7.1. A 30-min resuspension step was followed by a 5 -min ultra-high-shear mixing step using an UltraTurrax Model T25 instrument fitted with an S25N-18G dispersing tool (IKA Works Inc., Wilmington, NC). For the pilot plant treatments, the MCC powder was reconstituted with reverse osmosis water heated to $40^{\circ} \mathrm{C}$ and mixed with predetermined amounts of $1 \mathrm{M} \mathrm{NaOH}$, using a 5-min resuspension step followed by a 15-min high-shear dispersion step. All reconstituted $\mathrm{MCC}$ dispersions were stored at $4^{\circ} \mathrm{C}$ overnight to ensure full hydration and $\mathrm{pH}$ equilibration.

\section{Heating Treatments}

Benchtop Treatments. To evaluate the effect of heating temperature in the sterilization range on $\mathrm{MCC}$, samples were heated to $110,120,130,140$, and $150^{\circ} \mathrm{C}$, respectively. The heat treatments were performed in an insulated oil bath equipped with a recirculation heater (Thermomix 1480, UK Thermomix, Braun, Germany). During heating, MCC samples were placed in stainless steel tubes of 3/8-in. (0.95-cm) diameter, 0.02-in. (0.05$\mathrm{cm})$ wall thickness, and 7.12-in. (18.08-cm) length, closed at both ends with self-locking stainless steel cap fittings (Swagelok Company, Solon, OH). Thermocouples (type T) were mounted airtight into the stainless steel cap on one end and connected to an HH506 RA High Accuracy Datalogger/Thermometer (Omega Engineering Inc., Stamford, CT) for monitoring and acquisition of temperature data.

Five stainless steel tubes per temperature condition were filled with $\mathrm{MCC}$ and preheated to $40^{\circ} \mathrm{C}$, to ensure the same starting temperature for all samples. The tubes were submerged into the hot oil, and the timer was started instantly. The oil bath was set up so that samples reached the specified final temperatures in approximately $52 \mathrm{~s}$ for all heat treatment temperatures. This was done to eliminate the effect of the time needed to reach the required temperature on the MCC. Immediately after reaching the desired final temperature, the tubes were removed from the oil bath and placed on ice until the sample temperature reached $20^{\circ} \mathrm{C}$. The treated samples were pooled and subjected to chemical analyses.

Sterilization Treatments. The temperature and time combinations for the sterilization treatments were designed to ensure an equivalent microbial inactivation effect by calculating the lethality factor, $\mathbf{F}_{0}$. According to Bylund (2003), minimum $\mathrm{F}_{0}$ values of 5 to 6 are typically used to achieve commercially sterile milk.

The UHT treatment was performed on a pilot-scale MicroThermics heating system (Model $25 \mathrm{HV}$; MicroThermics Inc., Raleigh, NC), equipped with an Ultra Clean Fill Hood/Sterile Product Outlet (MicroThermics Inc.). The MCC preparations were preheated from the refrigeration temperature to $40^{\circ} \mathrm{C}\left(104^{\circ} \mathrm{F}\right)$ in a steam kettle and immediately subjected to the sterilization treatment. The following parameters were used for the final temperatures and times shown in Table 2: preheating within $20 \mathrm{~s}$, final heating of the product within $20 \mathrm{~s}$, holding at this temperature for the time indicated in Table 2, and cooling within $20 \mathrm{~s}$. The flow rate of the product was $2 \mathrm{~L} / \mathrm{min}$. The $\mathrm{F}_{0}$ value for the UHT treatment was calculated based on the average velocity of the product in the UHT unit.

An FMC Multipurpose Lab Retort with a LogTec Process Management System (Steritort, FMC, San Jose, CA) was used to batch-sterilize the MCC disper-

Table 2. Sterilization treatment conditions (temperature, holding time, $\mathrm{pH})$ designed to achieve the same lethality $\left(\mathrm{F}_{0}=6\right)$

\begin{tabular}{llcc}
\hline & & \multicolumn{2}{c}{$\mathrm{pH}$} \\
\cline { 3 - 4 } Treatment & $\begin{array}{l}\text { Holding } \\
\text { time }\end{array}$ & $\begin{array}{c}7.1 \\
\text { (unmodified) }\end{array}$ & 7.3 \\
\hline $\mathrm{UHT}, 135^{\circ} \mathrm{C} / 275^{\circ} \mathrm{F}$ & $15 \mathrm{~s}$ & $\mathrm{X}$ & $\mathrm{X}$ \\
$\mathrm{UHT}, 142^{\circ} \mathrm{C} / 288^{\circ} \mathrm{F}$ & $3 \mathrm{~s}$ & $\overline{\mathrm{X}}$ & $\mathrm{X}$ \\
Retorting, $115.6^{\circ} \mathrm{C} / 240^{\circ} \mathrm{F}$ & $21.3 \mathrm{~min}$ & $\mathrm{X}$ & $\mathrm{X}$ \\
Retorting, $121^{\circ} \mathrm{C} / 250^{\circ} \mathrm{F}$ & $6.1 \mathrm{~min}$ & $\mathrm{X}$ & $\mathrm{X}$ \\
\hline
\end{tabular}


sions in 8-oz (237-mL) Mason jars (Ball Corporation, Broomfield, CO). The product was treated in a still cook mode with cascading hot water. The temperature and time parameters, shown in Table 2 , were calculated from the temperature profile recorded in a preliminary trial by thermocouples attached to 4 jars located in the center of the retort. The calculations were performed with a modification of Ball's formula (Merson et al., 1978), using CALSoft 32 software, version 1.0 (TechniCAL Inc., Kenner, LA).

\section{pH Measurements}

The $\mathrm{pH}$ of the MCC samples was measured at $20^{\circ} \mathrm{C}$ using a Fisher Scientific Accumet Excel XL20 pH meter (Fisher Scientific, Pittsburgh, PA), calibrated at the measurement temperature before use.

\section{Particle Size Analysis}

Dynamic light scattering was used to evaluate particle size and particle size distributions in all samples following the procedure described in detail by Beliciu et al. (2012). The analyses were performed using a 90Plus Nanoparticle Size Analyzer equipped with a Peltier temperature control system (Brookhaven Instruments Corp., Holtsville, NY) at a fixed $90^{\circ}$ angle and a wavelength of $658 \mathrm{~nm}$.

Samples were equilibrated to $20^{\circ} \mathrm{C}$ in a water bath before analysis, with proper protection against dehydration. The samples where then diluted with UF permeate to the manufacturer's recommended signal intensity of 700 to 900 kilocounts per second. The UF permeate, obtained during the manufacture of the $\mathrm{MCC}$, was kept frozen at $-40^{\circ} \mathrm{C}$ and placed in a refrigerator at $4^{\circ} \mathrm{C}$ for $4 \mathrm{~d}$ before analysis for thawing. The particle size measurements were performed at a constant temperature of $20^{\circ} \mathrm{C}$, following an equilibration step.

Data collection and analysis was performed using the BIC software (Brookhaven Instruments Corp.). A dust cutoff filter parameter of 30 was used to ensure the quality of the measurements. Each measurement consisted of 8 subsequent individual runs of 30-s duration. All average diameters are reported as intensity-based means (referred to as the $Z$-average). The $Z$-average results from the instrument's internal calculations of the scattered intensity of the particle and the diameter of the particle. Measurements for each experimental condition were performed in duplicate.

\section{Ultracentrifugation Procedure}

To evaluate the mineral distribution between the soluble and insoluble phases and the dissociation of $\mathrm{CN}$ micelles as a result of the heat treatments, all MCC samples were subjected to an ultracentrifugation step. Samples were ultracentrifuged immediately after the heat treatment by transferring them into polycarbonate centrifuge bottles and centrifuging at 100,000 $\times g$ for $60 \mathrm{~min}$ at $20^{\circ} \mathrm{C}$, using a Beckman L8M centrifuge (Beckman Coulter Inc., Brea, CA) with a standard 70.1 titanium rotor at $38,200 \mathrm{rpm}$. Special care was taken not to resuspend the insoluble pellet while handling the ultracentrifuged samples. The resulting clear supernatant was collected using 10-mL syringes (Luer-Lock; Thermo Scientific, Waltham, MA) with 4-in. stainless steel needles from 4 bottles per sample and pooled.

\section{Mineral Profile Characterization}

The mineral composition of the ultracentrifugation supernatants was tested at the Dairy One Forage Analysis Laboratory (Ithaca, NY). Five grams of sample was weighed into calibrated CEM Xpress Teflon PFA vessels with fiberglass insulating sleeves (CEM Corporation, Matthews, NC). The samples underwent a 30-min digestion step with $8 \mathrm{~mL}$ of $\mathrm{HNO}_{3}$ and $2 \mathrm{~mL}$ of $\mathrm{HCl}$ at $1,600 \mathrm{~W}$ and $190^{\circ} \mathrm{C}$, in a CEM Microwave Accelerated Reaction System equipped with the MarsXpress Temperature Control option (CEM Corporation). The vessels were then brought to a $50-\mathrm{mL}$ volume with a $1.5 \mathrm{~N} \mathrm{HNO}_{3}+0.5 \mathrm{~N} \mathrm{HCl}$ solution to match the standards, aspirated, and analyzed with a Thermo Jarrell Ash IRIS Advantage HX Inductively Coupled Plasma Radial Spectrophotometer (Thermo Scientific, Madison, WI). The mineral analyses for each experimental condition were performed in duplicate.

\section{Quantification of Dissociated CN}

To evaluate dissociation of the $\mathrm{CN}$ micelle, individual $\mathrm{CN}$ were identified in the soluble phase after ultracentrifugation by using liquid chromatography coupled with tandem mass spectrometry by the Proteomics and Mass Spectrometry Core Facility at Cornell University (Ithaca, NY). Liquid chromatography coupled with tandem mass spectrometry couples the separation capabilities of HPLC, based on hydrophobic interactions between the stationary phase and the solute, with the detection power of mass spectrometry. Mass spectrometers ionize molecules and subsequently sort and identify them according to their mass-to-charge ratios. The identification of a protein, using the "bottom-up" or "shotgun" proteomics approach, is usually achieved via a 4 -step process consisting of protein digestion, protein separation, and mass spectrometry analysis of the resulting proteolytic fragments, followed by compari- 
son of the observed peptides with those in a database (O'Donnell et al., 2004).

Before the protein digestion, $0.2 \mathrm{p} M$ apomyglobin was added to $3 \mu \mathrm{L}$ of the ultracentrifuged supernatants as the internal standard. Apomyglobin is a protein standard that does not naturally occur in bovine dairy products. The protein mixtures were denatured with $3 \mathrm{M}$ guanidine $\mathrm{HCl}$, after which disulfide bonds were reduced using $16 \mathrm{mM}$ tris(2 carboxyethyl)phosphine during incubation at $60^{\circ} \mathrm{C}$ for $1 \mathrm{~h}$. The solution was treated with $42 \mathrm{mM}$ iodoacetamide for $1 \mathrm{~h}$ in the dark to alkylate cysteine residues, and then incubated with $26 \mathrm{mM}$ dithiothreitol for $10 \mathrm{~min}$. Before the addition of trypsin, samples were diluted with $100 \mathrm{~m} M$ Tris buffer for $\mathrm{pH}$ adjustment. Sequencing-grade trypsin was added to the solution in the concentration of $40 \mathrm{ng} / \mu \mathrm{g}$ to achieve a ratio of approximately 1:10 trypsin:protein, and the solution was incubated overnight at $37^{\circ} \mathrm{C}$. The resulting tryptic-digested peptides were diluted in a $1 \%$ formic acid: $10 \%$ acetonitrile solution.

The samples were desalted and separated on a C18 RP-HPLC column, connected in-line to a 4000 Q Trap triple quadrupole linear ion trap mass spectrometer equipped with a Turbo Ion Spray Head ion source (Applied Biosystems, Foster City, CA). The spray voltage was $2.0 \mathrm{kV}$ and was used in positive ion mode. Nitrogen was used as the collision gas. In information-dependent acquisition analysis, after each survey scan for $m / z 375$ to 1,600 and an enhanced resolution scan, the 3 highest intensity ions with multiple charge states were selected for tandem mass spectrometry, with rolling collision energy applied for detected ions based on different charge states and mass-to-charge ratio values. Data were evaluated using MultiQuant software 2.0 (AB Sciex, Framingham, MA).

\section{Statistical Analysis}

The experimental data were analyzed using JMP 8.0 software (SAS Institute Inc., Cary, NC). Analysis of variance was used to determine the effects of temperature and $\mathrm{pH}$. A general linear model was used to predict values for omitted $\mathrm{pH}$ and temperature conditions. Significant differences among samples were determined by Tukey's honestly significant difference test at $P \leq$ 0.05 .

\section{RESULTS AND DISCUSSION}

\section{Aggregation and Coagulation of MCC Under Different Temperature and $\mathrm{pH}$ Conditions}

The occurrence of particle aggregation in the heattreated samples was evaluated by determining the ef- fective particle diameter in the MCC samples (Figure 2 ). Values of the effective diameter at $\mathrm{pH}$ and temperature conditions omitted in the experimental design were estimated using a linear regression model based on statistical analysis of the data, and are indicated by an asterisk in Figure 2. The $\mathrm{pH}$, temperature, and their interaction had significant effects on particle size.

At pH 6.5 and 6.7, MCC samples showed strong aggregation after heating to 110 and $120^{\circ} \mathrm{C}$, and showed complete coagulation at temperatures of $130^{\circ} \mathrm{C}$ and above. In all cases, aggregation was visible to the naked eye, which rendered dynamic light scattering unusable for these $\mathrm{pH}$ conditions.

At $\mathrm{pH}$ 6.9, particle size increased significantly with increasing temperature, which points to aggregation of CN micelles in the treated MCC (Figure 2). The nonheat-treated control samples had an effective diameter of $224.5 \pm 35.8 \mathrm{~nm}$, which is slightly higher than what Beliciu and Moraru (2009) reported as the size for CN micelles in raw milk. After heat treatment at $150^{\circ} \mathrm{C}$, the effective particle diameter was $541.5 \pm 36.0 \mathrm{~nm}$, more than twice the size measured in the control.

At $\mathrm{pH} 7.1$, the unadjusted $\mathrm{pH}$ of the reconstituted MCC dispersions, the particle size measured in the control was $193.9 \pm 16.1 \mathrm{~nm}$, similar to the values reported by Beliciu and Moraru (2009). Only slight increases in size were observed after increasing the heat treatment temperature (Figure 2); after heating to $150^{\circ} \mathrm{C}$, an effective diameter of $229.0 \pm 25.3 \mathrm{~nm}$ was measured.

At $\mathrm{pH} 7.3$, virtually no differences in particle size were observed after heat treatment for all temperatures. The effective diameter of the non-heat-treated

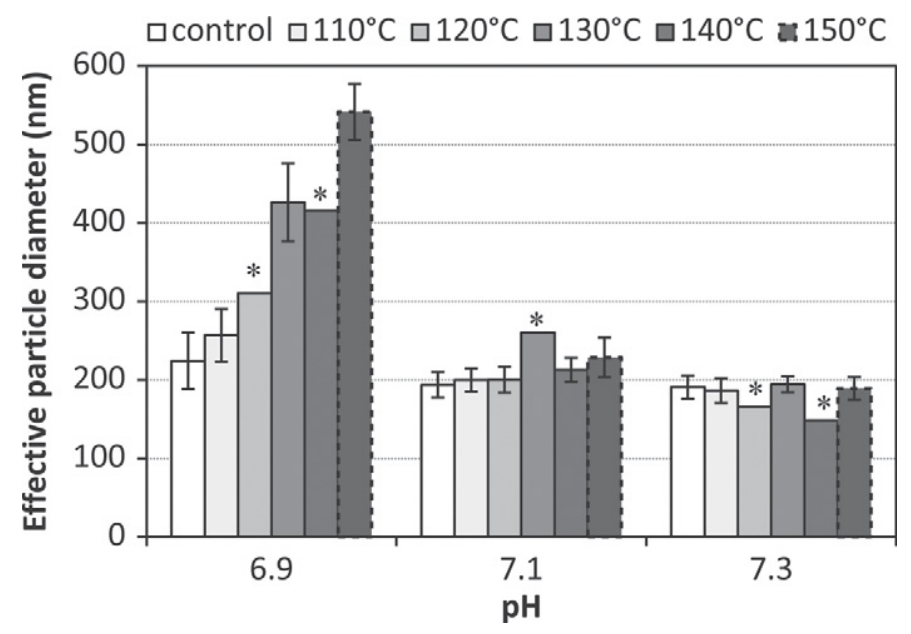

Figure 2. Particle size of untreated and heat-treated micellar CN concentrates at different $\mathrm{pH}$ values. Plotted are intensity-based effective mean diameters $(\mathrm{n}=3) \pm 1 \mathrm{SD}$. Asterisks $(*)$ indicate values estimated by the general regression model based on statistical analysis. 
control samples was comparable with those of the control samples at $\mathrm{pH}$ 7.1.

Zeta $(\xi)$-potential, as a measure of the electrical charge of the $\mathrm{CN}$ micelle, was determined as a relative indicator of colloidal stability of the MCC samples. The $\xi$-potential values for samples at all $\mathrm{pH}$ across the series of temperature treatments were in the range of -15 to $-25 \mathrm{mV}$ (data not shown). The $\xi$-potential became more negative with increasing $\mathrm{pH}$ and became less negative with increasing temperature treatment. Although the differences among the samples were not statistically significant, the observed trend supports the particle size data, showing less propensity for aggregation of the micelles at higher $\mathrm{pH}$.

\section{Changes in Mineral Solubility as a Function of $\mathrm{pH}$ and Temperature}

The total and soluble mineral profile of untreated, unmodified MCC can be found in Table 3. The main focus was placed on $\mathrm{Ca}$ and $\mathrm{P}$, the minerals that make up Ca phosphate, which has a critical role in the stability of the CN micelle. The concentrations of $\mathrm{Ca}$ and $\mathrm{P}$ in the soluble phase of heat-treated MCC samples across a range of $\mathrm{pH}$ values is presented in Figure $3 \mathrm{a}$ and $3 \mathrm{~b}$. Temperature had a significant effect on minerals in the serum phase, with the levels of $\mathrm{Ca}$ and $\mathrm{P}$ decreasing with an increasing heat treatment temperature across the investigated $\mathrm{pH}$ range. Levels of soluble $\mathrm{Ca}$ at $\mathrm{pH}$ 6.5 were significantly higher compared with those at higher $\mathrm{pH}$ (Figure 3a). No differences were observed in the soluble Ca concentration in the MCC samples treated at 140 and $150^{\circ} \mathrm{C}$ for $\mathrm{pH} 6.9$ or higher.

The effect of temperature on soluble $\mathrm{P}$ was similar to that of soluble Ca (Figure $3 \mathrm{~b}$ ). Soluble P levels did not change when $\mathrm{pH}$ was lowered, but increased when $\mathrm{pH}$ was increased; the highest levels of soluble $\mathrm{P}$ were detected in samples of $\mathrm{pH} 7.3$.

To better understand the effect of $\mathrm{pH}$ and thermal treatments on colloidal $\mathrm{Ca}$ phosphate, the $\mathrm{Ca}: \mathrm{P}$ ratios for all MCC samples were calculated. Calcium phosphate salts in milk can exist in different forms, which are characterized by different $\mathrm{Ca}: \mathrm{P}$ ratios (Gaucheron, 2005). The major form of colloidal Ca phosphate is tricalcium phosphate $\left[\mathrm{Ca}_{3}\left(\mathrm{PO}_{4}\right)_{2}\right]$, which corresponds
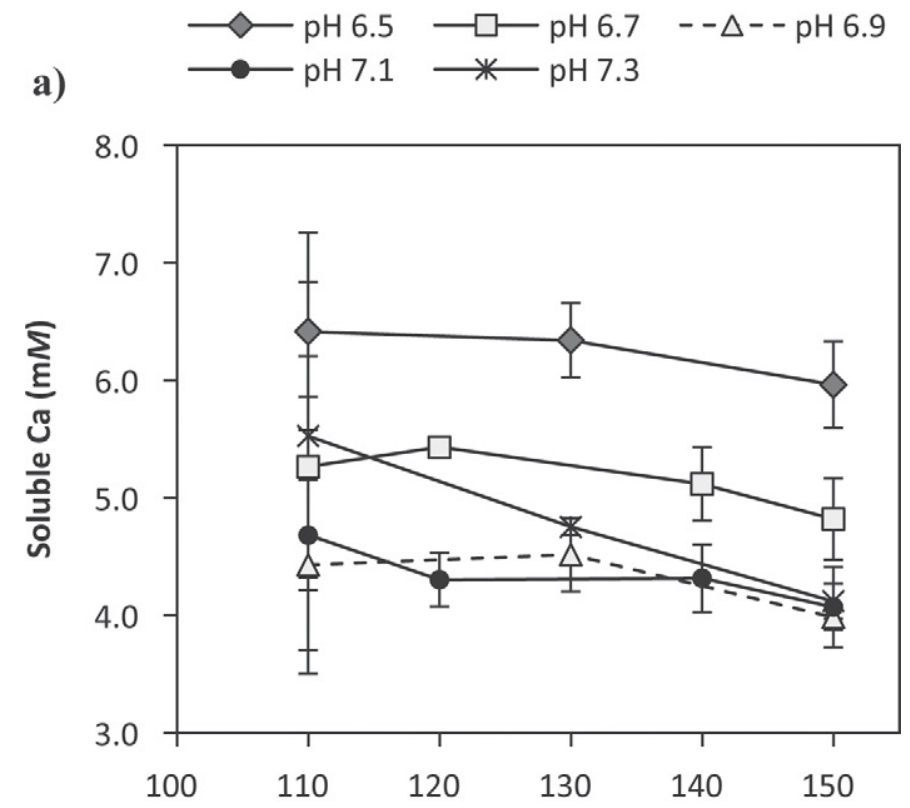

b)

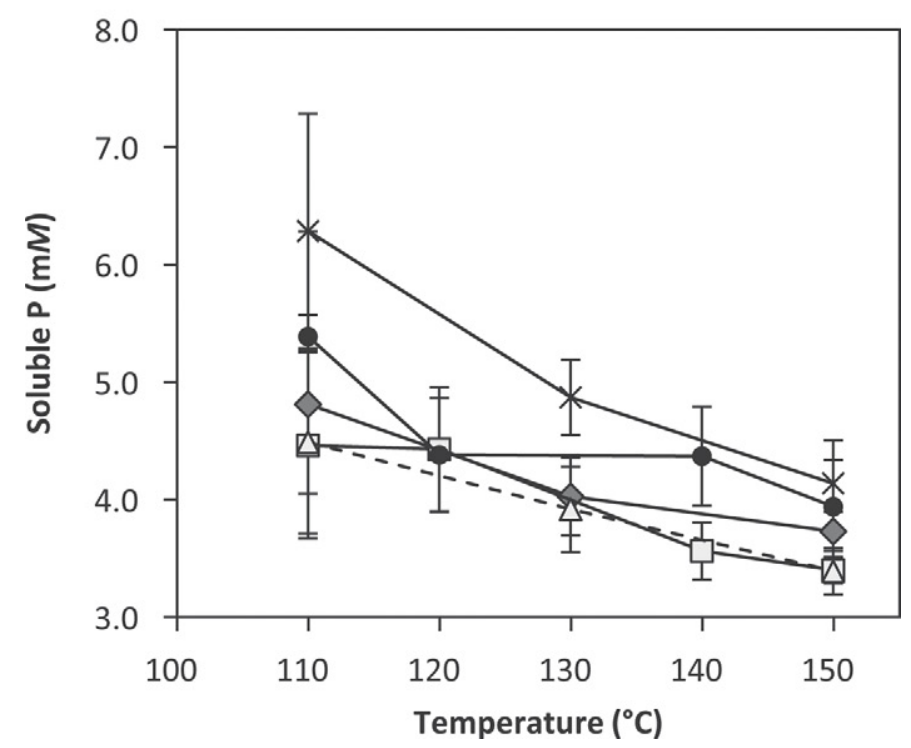

Figure 3. Mineral concentration in the soluble phase of heat-treated micellar CN concentrates: a) Ca; b) P. Plotted are mean values (n $=3) \pm 1 \mathrm{SD}$.

Table 3. Total and soluble mineral composition $(\mathrm{m} M)$ of the $\mathrm{pH}$-unadjusted $8 \%$ micellar $\mathrm{CN}$ concentrates $(\mathrm{MCC})^{1}$

\begin{tabular}{|c|c|c|c|c|c|c|}
\hline Item & \multicolumn{2}{|c|}{$\mathrm{Ca}$} & \multicolumn{2}{|c|}{$\mathrm{P}$} & \multicolumn{2}{|c|}{$\mathrm{Na}$} \\
\hline $8 \% \mathrm{MCC}$ & $69.5 \pm 5.35$ & $5.1 \pm 0.3$ & $62.7 \pm 11.7$ & $4.9 \pm 0.6$ & $6.8^{*}$ & $6.3^{*}$ \\
\hline
\end{tabular}

${ }^{1}$ Shown are the mean values $(\mathrm{n}=3) \pm 1 \mathrm{SD}$, unless otherwise noted. An asterisk $\left(^{*}\right)$ indicates only 2 replicates were available. 
to a Ca:P ratio of 1.5 (Cross et al., 2005; Lucey and Horne, 2009).

The Ca:P ratios in the soluble phase for all the MCC samples are plotted in Figure 4. For all heat treatments and the controls, Ca:P ratios decreased from approximately 1.5 at $\mathrm{pH} 6.5$ to approximately 1 at $\mathrm{pH}$ 7.3. Because no statistically significant differences were observed in the $\mathrm{Ca}: \mathrm{P}$ ratio between the controls and the samples treated at different temperatures for any of the $\mathrm{pH}$ levels, the average $\mathrm{Ca}: \mathrm{P}$ ratio across samples of a given $\mathrm{pH}$ and subjected to different temperatures was calculated and is shown as a fitted trend line in Figure 4. The average $\mathrm{Ca}: \mathrm{P}$ ratio at $\mathrm{pH} 7.1$, the unadjusted $\mathrm{pH}$ of the reconstituted MCC dispersions, was $0.98 \pm 0.07$; no difference was found in the Ca:P ratio between $\mathrm{pH}$ 7.1 and 7.3. A Ca:P ratio of 1 is comparable with the ratio found in the native serum phase of milk (Gaucheron, 2005).

Upon acidification, the $\mathrm{Ca}: \mathrm{P}$ ratio increased, reaching a value of $1.52 \pm 0.12$ at $\mathrm{pH}$ 6.5. This indicates that as $\mathrm{pH}$ decreased, colloidal Ca phosphate dissolved from the CN micelle and migrated into the serum phase. This is an expected and known effect, and has a significant contribution to the destabilization of $\mathrm{CN}$ micelles at low $\mathrm{pH}$ and their subsequent aggregation during the heat treatment.

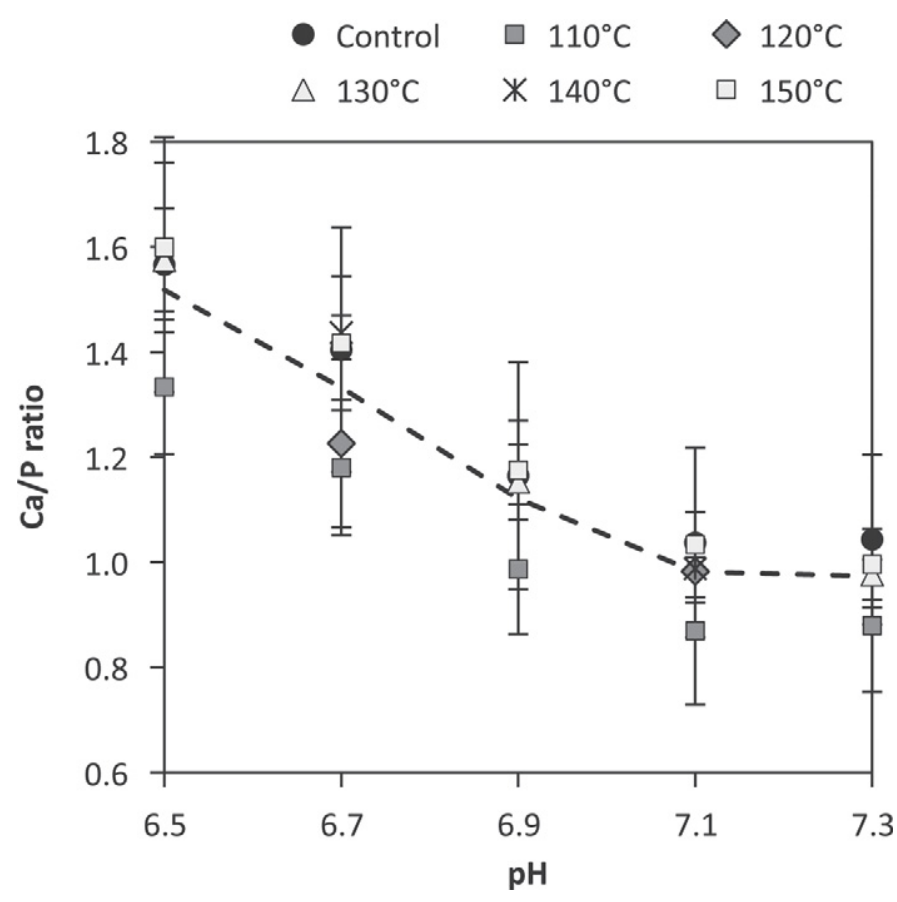

Figure 4. Calcium:phosphorus ratio for untreated and heat-treated micellar $\mathrm{CN}$ concentrates across the full range of $\mathrm{pH}$. Plotted are mean values $(\mathrm{n}=3) \pm 1 \mathrm{SD}$.

\section{Evaluation of CN Dissociation}

Dissociation of the $\mathrm{CN}$ micelles was evaluated by relative quantification of individual $\mathrm{CN}$ in the soluble phase after ultracentrifugation of heat-treated samples. A total of 23 peptides were identified as digestion products of $\alpha_{\mathrm{s} 1^{-}}, \alpha_{\mathrm{s} 2^{-}}, \beta-$, and $\kappa-\mathrm{CN}$ for the control and heattreated MCC samples, in addition to 6 peptides for the internal standard apomyoglobin. The nomenclature, peptide sequences, mass-to-charge-ratios, and retention times for these peptides are shown in Table 4. Generally, responses of the peptides from all $\mathrm{CN}$ followed the same trends but showed different intensities from peptide to peptide. For each type of $\mathrm{CN}$, the peptide with the strongest intensity response was selected as representative for the peptides of that $\mathrm{CN}$ and used as an indicator for dissociation in the MCC samples.

The non-heat-treated, $\mathrm{pH}$-unadjusted ( $\mathrm{pH}$ 7.1) MCC control samples showed a significant amount of soluble $\alpha_{\mathrm{s} 1^{-}}, \alpha_{\mathrm{s} 2^{-}}, \beta-$, and $\kappa^{-} \mathrm{CN}$ (Figure 5a). This was to be expected because not all $\mathrm{CN}$ are bound as $\mathrm{CN}$ micelles (Fox, 2003). The $\mathrm{pH}$ had a strong effect on $\mathrm{CN}$ dissociation, regardless of the temperature treatment. At lower $\mathrm{pH}$ (in the acidified samples), significantly less individual $\mathrm{CN}$ was observed in the soluble phase, which points toward CN aggregation and subsequent precipitation into the pellet upon ultracentrifugation. At $\mathrm{pH}$ 7.3, significantly higher amounts of individual CN were found in the supernatant, suggesting increased dissociation of $\mathrm{CN}$ from the $\mathrm{CN}$ micelle. Figure $5 \mathrm{~b}$ and $5 \mathrm{c}$ show data for the samples heated at 110 and $150^{\circ} \mathrm{C}$, but similar trends were obtained for the other heat treatment temperatures. The heat-treated samples showed the same trends observed for the controls, with increasing concentrations of soluble $\mathrm{CN}$ with increasing $\mathrm{pH}$ (Figure $5 \mathrm{~b}$ and $5 \mathrm{c}$ ). Across the $\mathrm{pH}$ range, soluble $\beta$ - and $\kappa-\mathrm{CN}$ were detected in much higher concentrations as compared with $\alpha_{\mathrm{s} 1^{-}}$and $\alpha_{\mathrm{s} 2^{-}} \mathrm{CN}$.

These observations are in agreement with previous reports, in which increasing amounts of dissociated $\alpha_{\mathrm{s}^{-}}$, $\beta-$, and $\kappa-\mathrm{CN}$ were observed with increasing $\mathrm{pH}$ from 6.5 to 7.1 upon heating skim milk from 80 to $120^{\circ} \mathrm{C}$ (Anema and Klostermeyer, 1997b) and whey proteinfree milk at 60 and $90^{\circ} \mathrm{C}$, respectively (Anema and $\mathrm{Li}$, 2000).

Figure 6 illustrates the effect of heating temperature on dissociation in samples of different $\mathrm{pH}$ values. Because of the different concentrations of the individual $\mathrm{CN}$ in the supernatant, in this analysis a relative change in dissociation was determined by comparing the concentration of each type of soluble $\mathrm{CN}$ in the heat-treated samples with the concentration of that $\mathrm{CN}$ in the control. This analysis did not include the samples for which visual aggregation or coagulation 
Table 4. Identified peptide names, peptide sequences, mass-to-charge ratio values for the first and second mass spectrometer (Q1 and Q3, respectively), and retention times (RT)

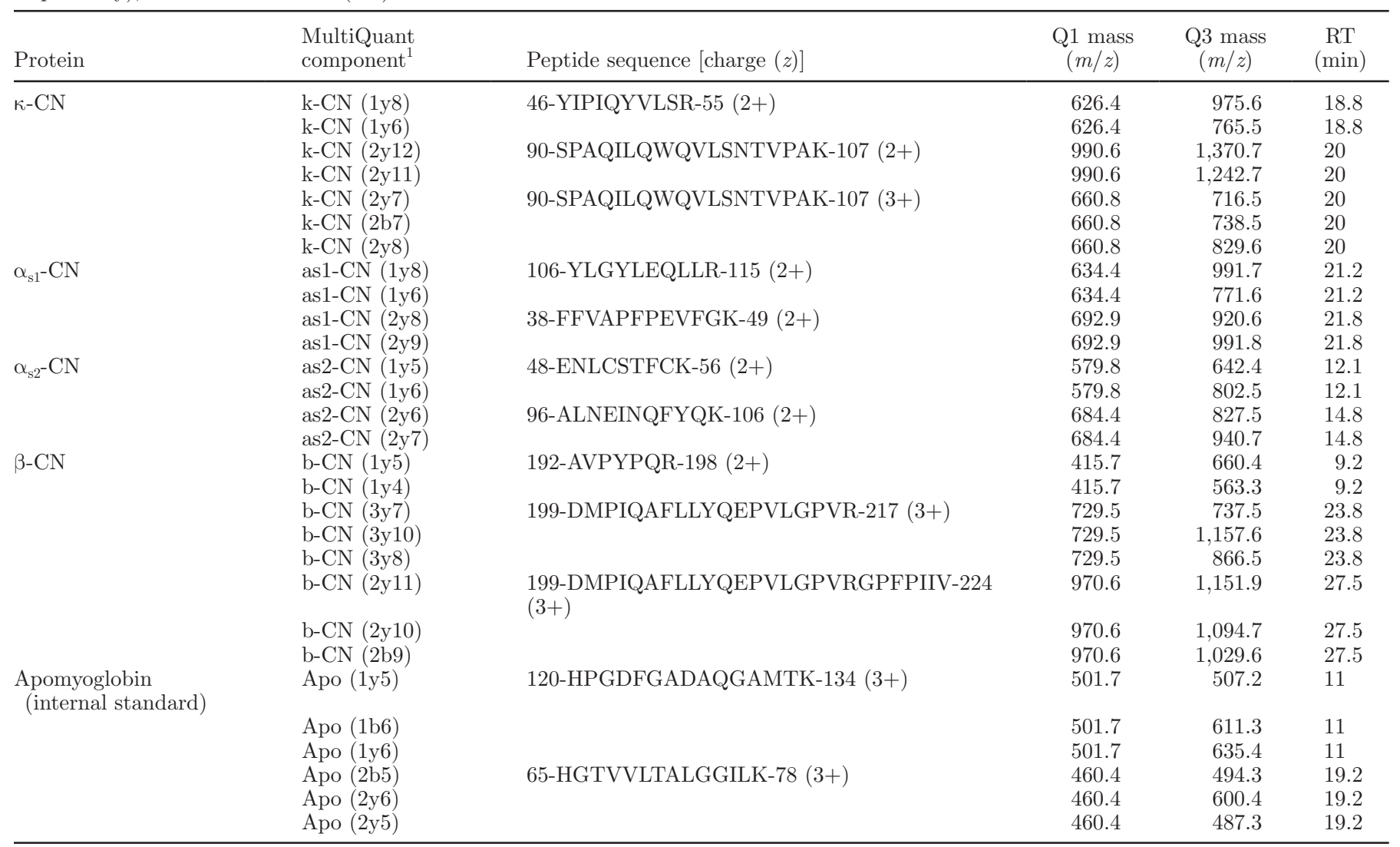

${ }^{1}$ MultiQuant software 2.0 (AB Sciex, Framingham, MA).

occurred (pH 6.5 and 6.7). At $\mathrm{pH} 6.9$ and 7.1, larger amounts of soluble $\beta$ - and $\kappa$-CN were observed with an increasing heat treatment temperature (Figure 6a and $6 \mathrm{~b})$. At $\mathrm{pH} 7.3$, levels of $\beta$ - and $\mathrm{\kappa}$-CN were comparable across the treatment temperature range (Figure 6c). Levels of soluble $\alpha_{\mathrm{s}^{-}}$and $\alpha_{\mathrm{s} 2^{-}} \mathrm{CN}$, however, decreased with increasing temperature at all $\mathrm{pH}$ levels, but the changes were most significant at $\mathrm{pH}$ 7.3. Anema and Klostermeyer (1997a) previously reported increasing dissociation of $\kappa-\mathrm{CN}$ and decreasing levels of $\alpha_{\mathrm{s}}-\mathrm{CN}$ when heating skim milk of different $\mathrm{pH}$ at temperatures from 70 to $90^{\circ} \mathrm{C}$.

These data showed that increasing the $\mathrm{pH}$ led to dissociation of the $\mathrm{CN}$ micelles in the non-heat-treated controls. The subsequent decreases in levels of $\alpha_{\mathrm{s} 1^{-}}$and $\alpha_{\mathrm{s}^{2}} \mathrm{CN}$ upon heating of $\mathrm{MCC}$ at $\mathrm{pH} 7.3$ suggest that the $\alpha_{\mathrm{s}}-\mathrm{CN}$ may form insoluble aggregates. This is possible when considering the fact that dissociated $\alpha_{\mathrm{s} 1^{-}}$ and $\alpha_{\mathrm{s} 2}-\mathrm{CN}$ will be present in the serum phase with a concentration of $\mathrm{Ca}$ of approximately $6 \mathrm{~m} M$ (see Table 3 ). It is known that $\alpha_{\mathrm{s} 1}-\mathrm{CN}$ can precipitate at $\mathrm{Ca}$ concentrations of 3 to $8 \mathrm{mM}$, and $\alpha_{\mathrm{s}^{2}}-\mathrm{CN}$ at about $2 \mathrm{mM}$ (Aoki et al., 1985). These aggregates are probably very small, which leads to a smaller average particle size in the heat-treated MCC samples of $\mathrm{pH} 7.3$ as compared with those at $\mathrm{pH} 6.9$ and 7.1 (Figure 2). Therefore, although an increase in $\mathrm{pH}$ will still lead to changes in the "native" CN micelles, it will prevent a visible aggregation and coagulation of MCC during high heat treatment.

It has previously been shown that the addition of 20 to $100 \mathrm{mM} \mathrm{NaCl}$ enhances the heat stability of milk and shifts the heat coagulation time-pH curve to more alkaline values, presumably because of the reduction of the negative micellar charge by $\mathrm{Na}^{+}$(Morrissey, 1969; Grufferty and Fox, 1985). The effects of $\mathrm{Na}$ in this study, however, were expected to be negligible because only a small concentration of $\mathrm{Na}^{+}$in the form of $\mathrm{NaOH}$ was added (1.83 $\mathrm{mM}$ of $\mathrm{NaOH}$ for adjustment from $\mathrm{pH}$ 7.1 to 7.3$)$.

\section{Evaluation of Commercial Sterilization Treatments with Modified Conditions}

The knowledge gained about the effects of $\mathrm{pH}$ and temperature on the stability of MCC in the benchtop 


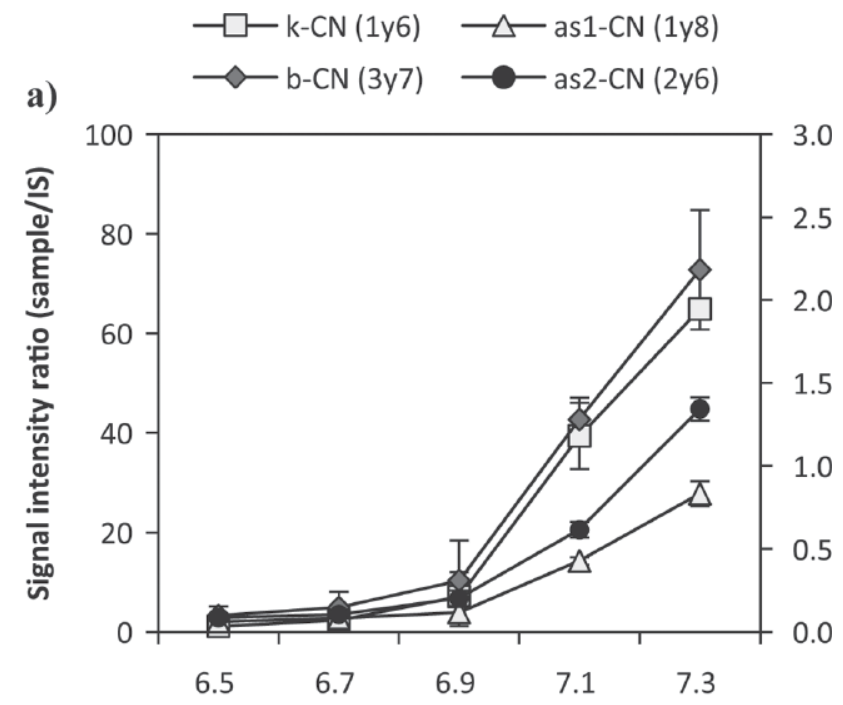

b)

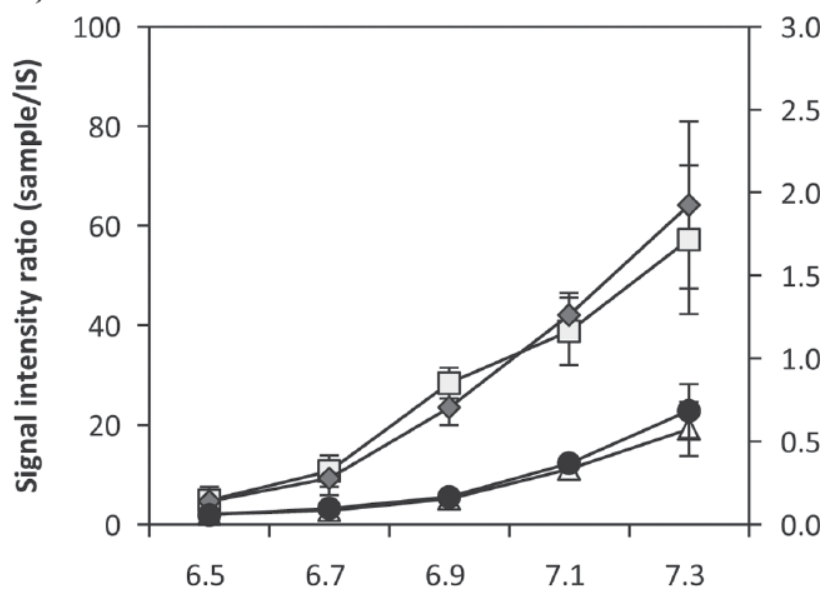

c)

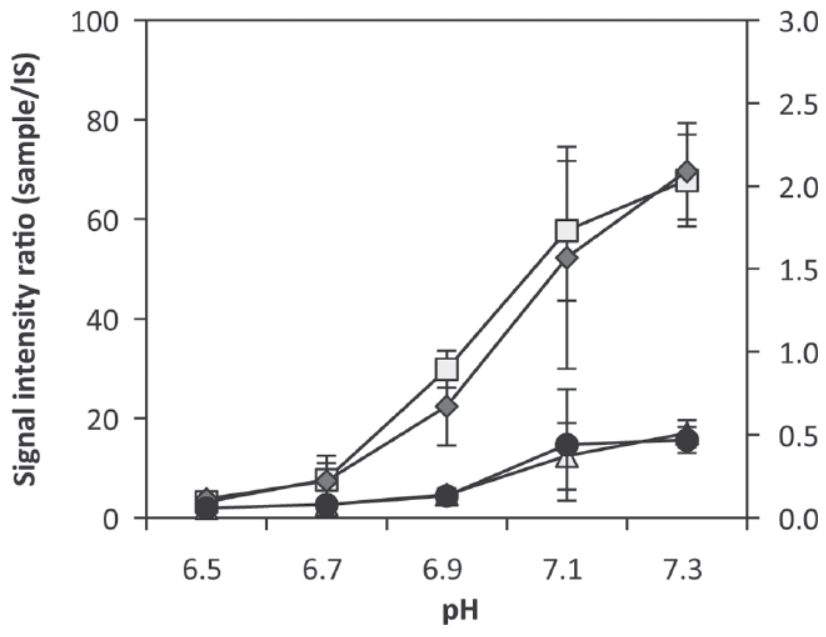

Figure 5. Casein dissociation, measured as the ratio of the signal intensity of a sample $\left(\alpha_{\mathrm{s} 1}, \beta, \kappa\right.$ on left axis; $\alpha_{\mathrm{s} 2}$ on right axis) divided by the signal intensity of the internal standard (IS) as function of $\mathrm{pH}$ in a) a control sample, b) samples heated to $110^{\circ} \mathrm{C}$, and c) samples heated to $150^{\circ} \mathrm{C}$. Plotted are mean values $(\mathrm{n}=3) \pm 1 \mathrm{SD}$. heating treatments was used to modify sterilization treatment conditions (both continuous-flow UHT treatment and batch retorting) such that the heat stability of MCC would be increased. On the basis of the results reported above, the $\mathrm{pH}$ of the $\mathrm{MCC}$ was adjusted to $\mathrm{pH} 7.3$, and sterilization treatment temperatures were decreased. The modified temperature-time combinations for the sterilization treatments were designed to ensure a microbial inactivation effect equivalent to that of the original treatments by calculating the $\mathrm{F}_{0}$ according to the method of Bylund (2003). The calculated $F_{0}$ value for all 4 treatments was 6 , which is in the range of values typically used to achieve commercially sterile milk (Bylund, 2003). The $\mathrm{pH}$, time, and temperature conditions used in these treatments are shown in Table 2.

A significant reduction in particle size was achieved in the MCC samples treated at lower sterilization temperatures, as compared with the original sterilization treatments, for both the adjusted and unadjusted $\mathrm{pH}$ (Figure 7). The smallest particle size was observed for MCC with adjusted $\mathrm{pH}$, retorted at 115.6 and $121^{\circ} \mathrm{C}$, with effective diameters of $211.2 \pm 3.7$ and $211.9 \pm$ $0.8 \mathrm{~nm}$, respectively. Visual observation of the samples after the sterilization treatment showed that samples retorted at the lower temperature, $115.6^{\circ} \mathrm{C}$ for $21.3 \mathrm{~min}$, showed significant browning as compared with the other heat-treated samples because of the long duration of the treatment.

The increase in $\mathrm{pH}$ also resulted in a decreased effective diameter for the control, UHT-treated, and retorted samples. The control sample of $\mathrm{pH} 7.1$ had an effective diameter of $255.3 \pm 6.0 \mathrm{~nm}$, as compared with $236.8 \pm$ $7.1 \mathrm{~nm}$ in the $\mathrm{pH} 7.3$ control sample. These reductions in particle size were significant; statistically significant differences between the 2 levels of $\mathrm{pH}$ are indicated by capital letters in Figure 7, and differences among heat treatments within $1 \mathrm{pH}$ category are indicated by small letters.

It must also be noted that the particle size for the control MCC in this part of the study was larger as compared with the benchtop heat treatments. This difference can be attributed to the different reconstitution methods used in the 2 situations, caused by the very different amounts of samples that were handled in the 2 situations.

Evaluation of $\mathrm{Ca}$ and $\mathrm{P}$ content in the serum phase showed significantly lower levels of soluble minerals in the heat-treated MCC as compared with the control samples; both soluble Ca and $\mathrm{P}$ concentrations were approximately $2 \mathrm{~m} M$ lower in the heat-treated MCC than in the untreated control samples. However, no differences were observed in soluble $\mathrm{Ca}$ and $\mathrm{P}$ between the 4 different sterilization treatments, both within the same 


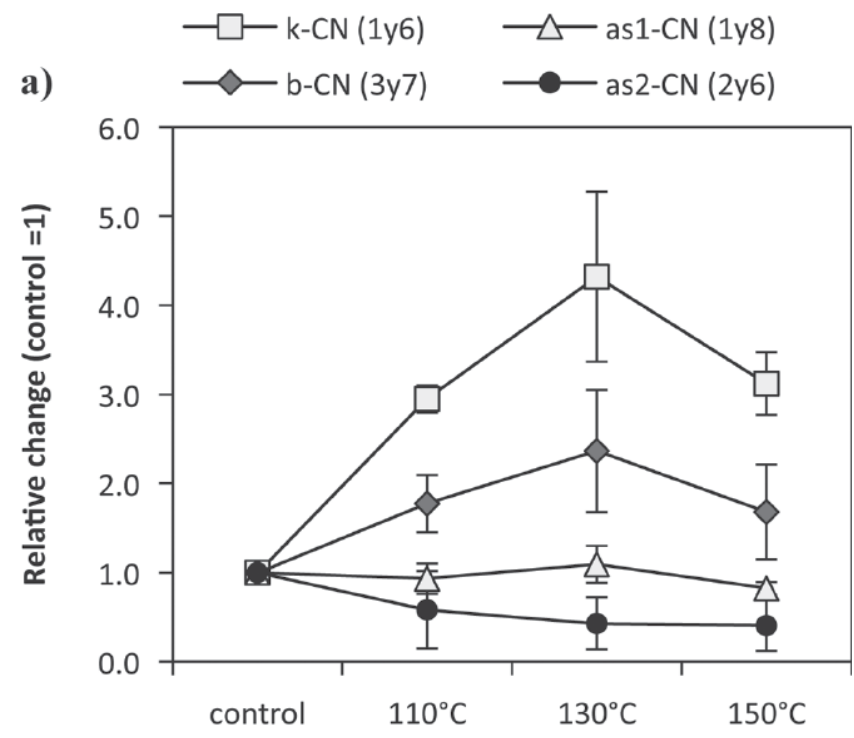

b)

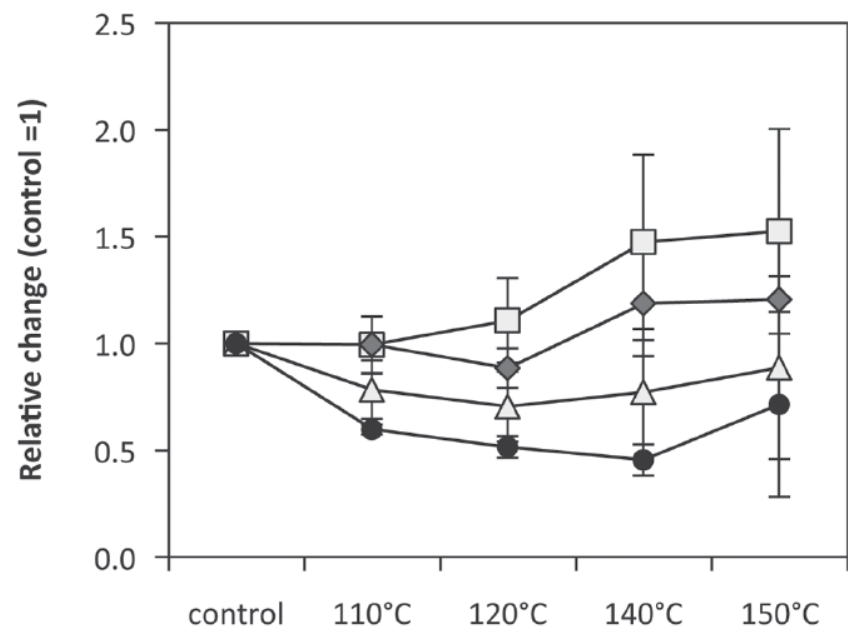

c)

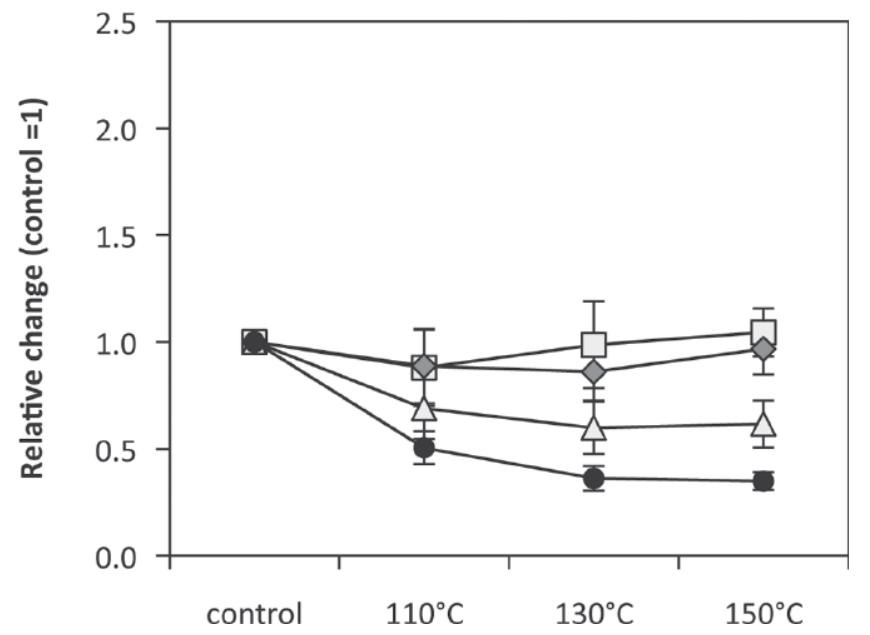

Figure 6. Relative change of $\mathrm{CN}$ dissociation with increasing temperature at a) $\mathrm{pH} 6.9$, b) $\mathrm{pH} 7.1$, and c) $\mathrm{pH}$ 7.3. The dissociation level in the control treatment equals 1 . Plotted are mean values $(\mathrm{n}=3) \pm$ $1 \mathrm{SD}$.

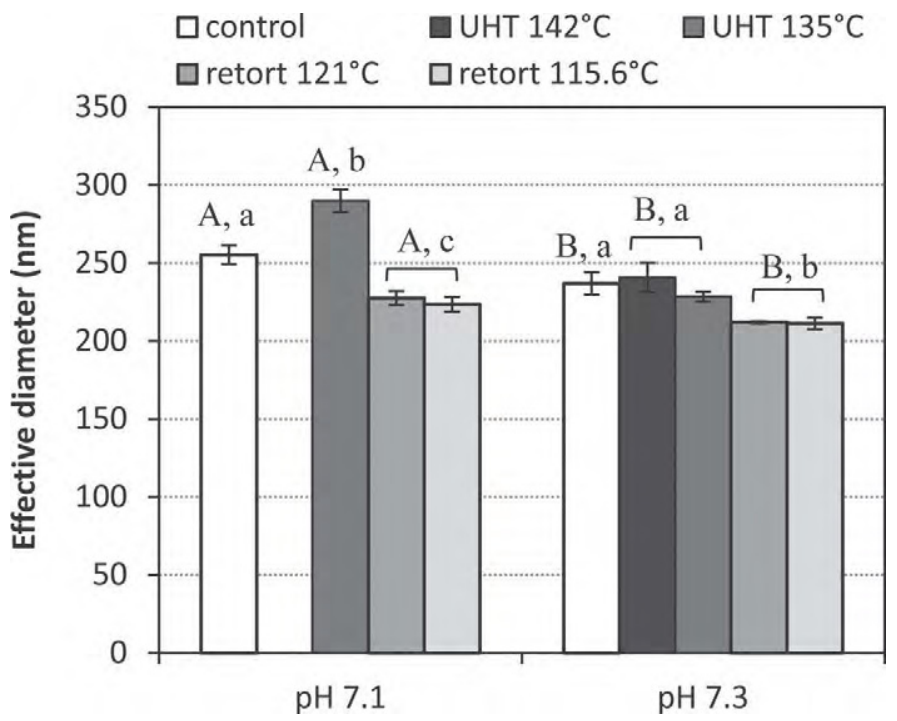

Figure 7. Particle size of micellar CN concentrates untreated and heat-treated by sterilization treatments. Treatments not connected by the same capital letter $(\mathrm{A}, \mathrm{B})$ are different across the $2 \mathrm{pH}$ categories. Treatments not connected by the same small letter $(\mathrm{a}-\mathrm{c})$ are different within the same $\mathrm{pH}$ category. Plotted are intensity-based effective mean diameters $(\mathrm{n}=3) \pm 1 \mathrm{SD}$.

$\mathrm{pH}$ group and between the 2 different $\mathrm{pH}$ levels (data not shown). Calculation of the Ca:P ratio indicated no effect of $\mathrm{pH}$ on this ratio for all heat treatments; however, significant differences were observed in the Ca:P ratio among the different heat treatments. The average Ca:P ratio for the control samples at both $\mathrm{pH}$ levels was $1.06 \pm 0.06$, which decreased to $0.98 \pm 0.06$ in the samples sterilized by UHT treatment at $135^{\circ} \mathrm{C}$. A similar Ca:P ratio was observed for the product sterilized by UHT treatment at $142^{\circ} \mathrm{C}$. The average Ca:P ratios for retorted MCC at 115.6 and $121^{\circ} \mathrm{C}$ were 0.88 \pm 0.05 and $0.91 \pm 0.05$, respectively. Overall, the duration of heating, rather than the treatment temperature, seemed to have an effect on the Ca:P ratio because the lowest Ca:P ratio was observed for the MCC treated at the lowest sterilization temperature, with the longest hold time.

The effect of sterilization treatments on the dissociation of $\mathrm{CN}$ is presented as the relative change in the amount of $\mathrm{CN}$ in the soluble phase (Figure 8). Distinct differences were observed in the dissociation of $\mathrm{CN}$ among the different sterilization treatments at either natural $\mathrm{pH}$ or $\mathrm{pH}$ adjusted to a higher value. At $\mathrm{pH} 7.1$, a strong dissociation of $\kappa$-CN was detected after retorting at both temperatures, whereas the UHT treatment showed no difference in dissociation compared with the control. The dissociation behavior of $\beta-\mathrm{CN}$ was comparable with that of $\kappa$ - $\mathrm{CN}$ but was less pronounced for the retorted samples. Significantly less $\alpha_{\mathrm{s}^{-}}$and $\alpha_{\mathrm{s} 2^{-}} \mathrm{CN}$ 
a)
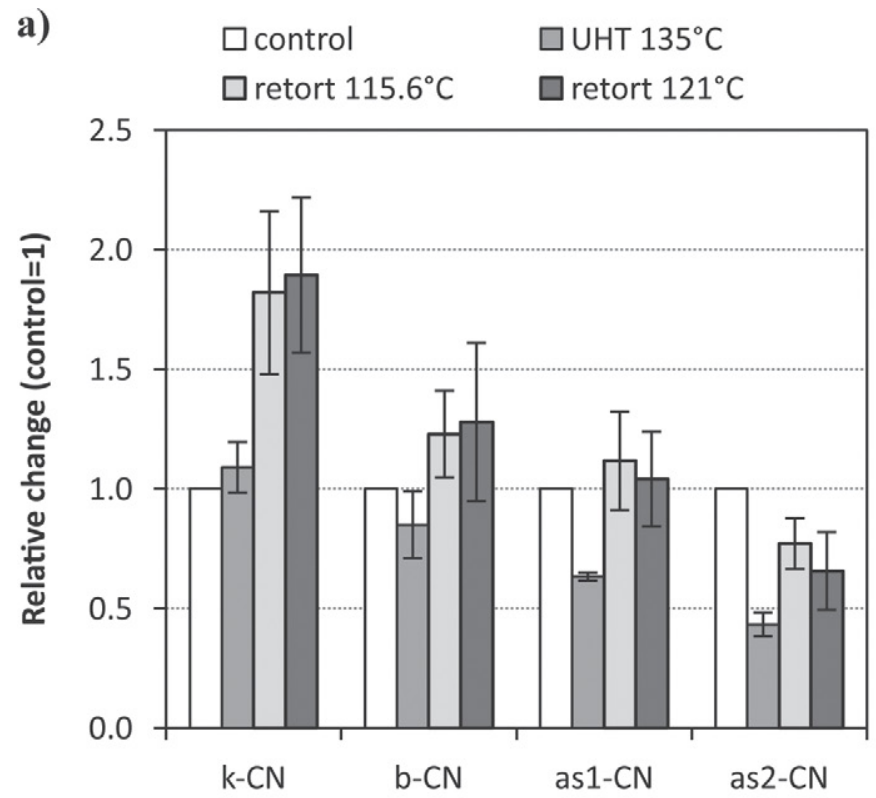

b)
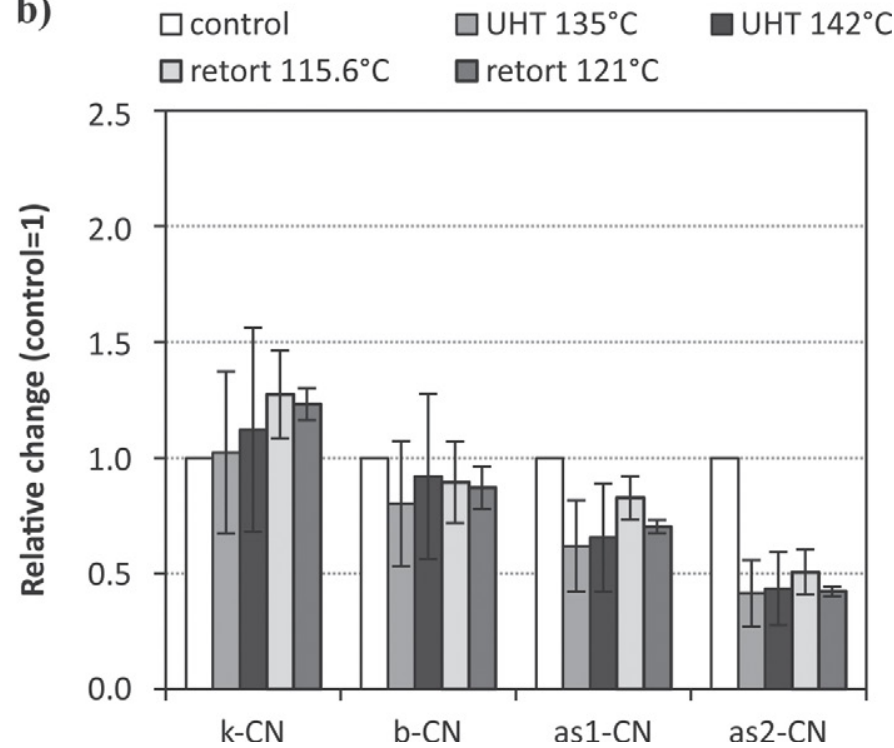

Figure 8. Relative change in $\mathrm{CN}$ dissociation after commercial sterilization treatments for a) unadjusted $\mathrm{pH}(\mathrm{pH} 7.1)$, and b) adjusted $\mathrm{pH}(\mathrm{pH}$ 7.3). Plotted are mean values $(\mathrm{n}=3) \pm 1 \mathrm{SD}$.

were found in the soluble phase after UHT treatment, whereas retorting had only a small effect on the dissociation of these $2 \mathrm{CN}$. At $\mathrm{pH} 7.3, \kappa-$ and $\beta-\mathrm{CN}$ showed no distinct differences in dissociation between different sterilization treatments; however, the levels of soluble $\alpha_{s 1^{-}}$and $\alpha_{\mathrm{s} 2^{-}} \mathrm{CN}$ were both significantly lower after all heat treatments. These findings confirm the hypothesis formulated after the benchtop study: as $\mathrm{k}-\mathrm{CN}$ is dissociating from the micelle, protection for Ca-sensitive $\mathrm{CN}$ against soluble $\mathrm{Ca}$ is lost, and $\alpha_{\mathrm{s} 1^{-}}$and $\alpha_{\mathrm{s} 2^{-}} \mathrm{CN}$ will participate in the formation of aggregates. The aggre- gates present in the $\mathrm{pH}$-adjusted, heat-treated MCC will most likely have a different composition and will be slightly smaller than the original CN micelles. They will, however, be small enough to stay in dispersion and not form large aggregates, thus allowing their use in protein-based formulations.

\section{CONCLUSIONS}

The main conclusion of this study is that MCC is unstable in response to heat temperature treatments in the sterilization range, and this instability increases with treatment temperature. At high temperatures, changes in the mineral equilibrium and partial disintegration of the CN micelle occur, which lead to aggregation and even coagulation. The aggregation and coagulation of MCC can be prevented by increasing the $\mathrm{pH}$ or decreasing the temperature of the heat treatment, or both. These findings will help processors design appropriate sterilization conditions for products with a high MCC content, and identify new opportunities for product development.

\section{ACKNOWLEDGMENTS}

The authors thank the New York State Milk Promotion Advisory Board (Albany, NY) for funding this research. We thank D. M. Barbano, Emily Hurt, Michael Adams, Chassidy Coon, Sean Schell, Tom Gibson, and the Dairy Plant staff from the Department of Food Science at Cornell University (Ithaca, NY) for help with processing of the $\mathrm{CN}$ concentrates.

\section{REFERENCES}

Affertsholt, T. 2009. The market for dairy ingredients based on separation technology. Presented at The World Market for Milk Ingredients 2008-2011. 3A Business Consulting, Aarhus, Denmark

Anema, S. G., and H. Klostermeyer. 1997a. Heat-induced, pH-dependent dissociation of casein micelles on heating reconstituted skim milk at temperatures below $100^{\circ} \mathrm{C}$. J. Agric. Food Chem. 45:1108-1115.

Anema, S. G., and H. Klostermeyer. 1997b. The effect of pH and heat treatment on the kappa-casein content and the zeta-potential of the particles in reconstituted skim milk. Milchwissenschaft $52: 217-223$.

Anema, S. G., and Y. Li. 2000. Further studies on the heat-induced, $\mathrm{pH}$-dependent dissociation of casein from the micelles in reconstituted skim milk. Lebenson. Wiss. Technol. 33:335-343.

AOAC International. 2000. Official Methods of Analysis of AOAC International. 17th ed., AOAC Int., Gaithersburg, MD.

Aoki, T., K. Toyooka, and Y. Kako. 1985. Role of phosphate groups in the calcium sensitivity of $\alpha$ s-casein. J. Dairy Sci. 68:1624-1629.

Beliciu, C. M., and C. I. Moraru. 2009. Effect of solvent and temperature on the size distribution of casein micelles measured by dynamic light scattering. J. Dairy Sci. 92:1829-1839.

Beliciu, C. M., A. Sauer, and C. I. Moraru. 2012. The effect of commercial sterilization regimes on micellar casein concentrates. J. Dairy Sci. 95. http://dx.doi.org/10.3168/jds.2011-4875. 
Brans, G., C. G. P. H. Schroen, R. G. M. van der Sman, and R. M Boom. 2004. Membrane fractionation of milk: State of the art and challenges. J. Membr. Sci. 243:263-272.

Bylund, G. 2003. Dairy Processing Handbook. Tetra Pak Processing Systems AB, Lund, Sweden.

UBIC Consulting. 2010. Milk protein concentrate ingredient market. Milk protein concentrate and total milk protein update. UBIC Consulting, Sierre, Switzerland.

Cross, K. J., N. L. Huq, J. Palamara, J. W. Perich, and E. C. Reynolds. 2005. Physicochemical characterization of casein phosphopeptide-amorphous Ca phosphate nanocomplexes. J. Biol. Chem. 280:15362-15369.

Fox, P. F. 1982. Heat-induced coagulation of milk. Pages 189-228 in Developments in Dairy Chemistry-1. P. F. Fox, ed. Applied Science Publishers, London, UK.

Fox, P. F. 2003. Milk proteins: General and historical aspects. Pages 1-48 in Advanced Dairy Chemistry. Vol. 1: Proteins. 3rd ed. P. F. Fox and P. L. H. McSweeney, ed. Kluwer Academic, New York.

Gaucheron, F. 2005. The minerals of milk. Reprod. Nutr. Dev. 45:473-483.

Grufferty, M. B., and P. F. Fox. 1985. Effect of added NaCl on some physicochemical properties of milk. Ir. J. Food Sci. Technol. 9:1-9

Hurt, E., and D. M. Barbano. 2010. Processing factors that influence casein and serum protein separation by microfiltration. J. Dairy Sci. 93:4928-4941.
Hurt, E., J. Zulewska, M. Newbold, and D. M. Barbano. 2010. Micellar casein concentrate production with a $3 \times$, 3-stage, uniform transmembrane pressure ceramic membrane process at $50^{\circ} \mathrm{C}$. J. Dairy Sci. 93:5588-5600.

Lucey, J. A., and D. S. Horne. 2009. Milk salts: Technological significance. Pages 351-389 in Advanced Dairy Chemistry. Vol. 3 Lactose, Water, Salts, and Minor Constituents. 3rd ed. P. F. Fox and P. L. H. McSweeney, ed. Springer Science+Business Media LLC, New York, NY

Merson, R. L., R. P. Singh, and P. A. Carroad. 1978. An evaluation of Ball's formula method of thermal process calculations. Food Technol. 32:66-72, 75 .

Morrissey, P. A. 1969. Heat stability of milk as affected by variations in pH and milk salts. J. Dairy Res. 36:343-351.

Nelson, B. K., and D. M. Barbano. 2005. A microfiltration process to maximize removal of serum proteins from skim milk before cheese making. J. Dairy Sci. 88:1891-1900.

O'Donnell, R., J. W. Holland, H. C. Deeth, and P. Alewood. 2004 Milk proteomics. Int. Dairy J. 14:1013-1023.

Sauer, A., and C. I. Moraru. 2011. Stability of sterilized micellar casein concentrates (MCC) during storage. J. Dairy Sci. 94(E-Suppl. 1):57-58. (Abstr.) 